\title{
Kinerja OCB pada guru PAUD ditinjau dari Educational leadership dan Integritas
}

\author{
Tuti Rosyati ${ }^{\varpi_{1}}$, Saprudin ${ }^{2}$, Ahmad Syukron ${ }^{3}$ \\ Ilmu Administrasi, Sekolah Tinggi Ilmu Administrasi Menara Siswa \\ DOI: $\underline{10.31004 / \text { obsesi.v5i1.513 }}$
}

\begin{abstract}
Abstrak
Penelitian ini bertujuan untuk mengetahui kinerja ocb (perilaku warga organisasi) dalam hal kepemimpinan pendidikan, dan integritas pada guru anak usia dini di Kabupaten Bogor. Metode yang digunakan adalah survei dengan studi korelasional yang melibatkan 94 sampel. Ada instrumen yang mengukur kinerja ocb (perilaku kewarganegaraan organisasi) (rel. 812), kepemimpinan pendidikan (rel .796), dan integritas (rel. 915). Hubungan antara variabel kepemimpinan pendidikan dengan kinerja (perilaku warga organisasi) dilakukan analisis regresi sederhana. Hasil analisis regresi sederhana ini mendapatkan persamaan $\hat{Y}=$ $52,409+0,511 X 1$ dengan Fhitung sebesar 77,04 dan 1,195. Hubungan antara variabel integritas guru dengan kinerja (perilaku warga organisasi) dilakukan analisis regresi sederhana. Hasil analisis regresi sederhana ini mendapatkan persamaan $\hat{Y}=52,079+0,532 X 2$ dengan Fhitung sebesar 75,89 dan 1,573, dan hubungan antara variabel kepemimpinan pendidikan (X1), kompetensi guru (X2) bersama-sama dengan kinerja (perilaku warga organisasi) $(Y)$ dilakukan analisis regresi berganda. Hasil analisis regresi berganda yang menghasilkan persamaan regresi $\hat{Y}=47,806+0,281 X 1+0,277 X 2$ dengan Fhitung sebesar 43,102 .
\end{abstract}

Kata kunci: kepemimpinan pendidikan, integritas, kinerja ocb

\begin{abstract}
This study aims to determine the performance of OCB (organizational citizenship behavior) in terms of Educational leadership, and integrity at early childhood teachers in Bogor District. The method used is a survey with a correlational study involving 94 samples. There are instruments that measure OCB performance (organizational citizenship behavior) (rel. 812), Educational leadership (rel. 796), and integrity (rel. 915). The results of this simple regression analysis get the equation $\hat{Y}=52.409+0.511 X 1$ with Fcount of 77.04 and 1.195. The relationship between teacher integrity variables and performance (organizational citizenship behavior) was carried out by simple regression analysis. The results of this simple regression analysis get the equation $\hat{Y}=52.079+0.532 X 2$ with Fcount of 75.89 and 1.573, and the relationship between Educational leadership variables (X1), teacher integrity (X2) together with performance (organizational citizenship behavior) $(Y)$ performed multiple regression analysis. The results of multiple regression analysis that produces a regression equation $\hat{Y}=$ $47.806+0.281 X 1+0.277 X 2$ with Fcount of 43.102.
\end{abstract}

Keywords: educational leadership, integrity, performance ocb

Copyright (c) 2020 Tuti Rosyati, Saprudin, Ahmad Syukron

$\triangle$ Corresponding author :ahmadsyukron69@gmail.com

Email Address : tuty.rosyati@menarasiswa.ac.id (Bogor, Jawa Barat, Indonesia)

Received 9 April 2020, Accepted 28 May 2020, Published 28 May 2020 


\section{PENDAHULUAN}

Profesi keguruan mempunyai dimensi yang sangat luas dan dalam, mulai dari pemahaman secara mendalam tentang wawasan yang mendasari pergaulan pendidikan antara guru-siswa. Penguasaan materi ajar, sampai pada pemahaman tentang latar keadaan dimana atau dalam lingkungan apa tindakan pendidikan itu harus dilakukan. Dengan kata lain seorang guru harus secara tepat menggunakan pertimbangan profesional (professional judgement) dalam bertindak dan menjawab tantangan masalah yang dihadapi dalam tugasnya.

Dalam melaksanakan tugas, guru harus memiliki kompetensi dan profesionalisme agar dapat menjalankan tugas dengan sebaik-baiknya. Guru memegang peranan yang sangat penting dalam peningkatan mutu pendidikan pada suatu sekolah. Untuk menjalankan perannya tersebut guru harus memiliki kemampuan. Hal ini sesuai dengan pendapat Aqib yang manyatakan bahwa guru adalah faktor penentu bagi keberhasilan pendidikan di sekolah, karena guru merupakan sentral serta sumber kegiatan belajar mengajar (Aqib, 2002). Lebih lanjut dinyatakan bahwa guru merupakan komponen yang berpengaruh dalam peningkatan mutu pendidikan di sekolah. Hal ini menunjukkan bahwa kemampuan atau kompetensi seorang guru sangat menentukan mutu pendidikan utamanya pada lembaga Pendidikan Anak Usia Dini (PAUD).

Kompetensi yang harus dimiliki guru PAUD paling tidak harus memenuhi standar. Standar kompetensi Guru dapat diartikan sebagai suatu pernyataan tentang kriteria yang dipersyaratkan, ditetapkan dan disepakati bersama dalam bentuk pengetahuan, keterampilan dan sikap bagi seorang tenaga kependidikan sehingga layak disebut kompeten (Mundia Sari \& Setiawan, 2020). Dengan kompetensi tersebut guru dianggap sebagai sosok pribadi yang diteladani karena mampu menunjukkan keutamaan-keutamaan (virtues) dalam praktek dan tingkah laku hidupnya. Guru hormat pada kejujuran, setia dalam ketekunan (Educational leadership), luwes dalam bergaul dengan berbagai kalangan, memegang teguh kedisiplinan, dan mencintai anak didiknya. Kompetensi guru berkaitan erat dengan kinerjanya sebagai guru.

Kinerja organizational citizenship behavior (OCB) yang merupakan bagian dari perilaku extra-role juga perlu mendapatkan perhatian khusus. Hal ini disebabkan karena masih kurangnya motivasi guru dalam melakukan perilaku extra-role di suatu sekolah. Para guru lebih banyak melakukan perilaku extra-role dalam keadaan terpaksa dan bukan karena keinginan dan kesukarelaan untuk memajukan sekolah.

Kinerja OCB menurut para ahli akan memberikan kontribusi yang positif bagi organisasi. Hal ini seperti yang diungkap oleh para ahli bahwa pada tingkat organisasi, studi mengindikasikan bahwa kinerja OCB berhubungan dengan efektivitas organisasi (Moideenkutty, 2005). Berdasarkan penjelasan dan penelitian para ahli tersebut sangatlah tepat jika banyak sekolah swasta jalan di tempat dan tidak mengalami kesuksesan program sekolah dikarenakan kurangnya perilaku kinerja OCB di lingkungan sekolah.

Berdasarkan kenyataan yang ada mengenai kurangnya perilaku extra-role tersebut maka perlu bagi pimpinan organisasi untuk membangkitkan perilaku tersebut dengan memberikan reward nonformal ataupun mengembangkan reward sebagai sistem formal dalam organisasi. Contoh ini bisa kita lihat dari cara yang dilakuan oleh John Brady, seorang presiden direktur dari John Braddy Design Consultant dalam mengetahui kinerja OCB seseorang, dimana dia memberikan beberapa kantong kelereng di awal tahun kepada semua pegawainya. Ketika ada pegawai yang membantu pegawai lain, maka pegawai tersebut akan memperoleh kelereng. Ketika di akhir tahun maka akan dihitung kelereng masingmasing pegawai tersebut. Yang terbanyak memiliki kelereng maka dia akan memperoleh hadiah walaupun tidak banyak (George \& Jones, 2002).

Setiap anggota organisasi harus membangun sikap mementingkan kepentingan orang lain, membangun kesadaran yang tinggi, berjiwa sosial, jujur atas segala sesuatu, dan sopan santun. Jika beberapa sikap tersebut terbangun tentu akan membangkitkan hidup 
organisasi. adapun faktor-faktor yang berhubungan dengan kinerja (organizational citizenship behavior) adalah Educational leadership dan integritas.

Educational leadership salah satu kekuatan karakter yang merupakan kelanjutan dari tindakan sukarela yang dilakukan untuk mencapai suatu tujuan meskipun ada hambatan, kesulitan atau keputusasaan. Kurangnya ketekunan adalah kelemahan yang lazim di antara kebanyaan orang. Ini adalah kelemahan yang mungkin bisa di atasi dengan usaha. Mudah tidaknya menaklukan dan kurangnya ketekunan, sangat tergantung pada intensitas hasrat seseorang. Jika hasrat seseorang meningkat tentu nilai ketekunan akan ikut meningkat juga.

Integritas merupakan menjalankan tugas dan pekerjaan dengan selalu memegang teguh kode etik dan prinsip-prinsip moral. Ketika perilaku seorang guru selaras dengan standar yang dikenal dan nilai-nilai yang dianut dan mempraktekkan apa yang dipercayai, berarti guru tersebut memiliki integritas. Ketika guru mengatakan satu hal tetapi melakukan sesuatu yang lain, guru tersebut tidak berintegritas. Ketika melihat lebih dekat faktor-faktor yang berkontribusi terhadap persahabatan yang hangat, karier dan organisasi yang sukses, dan sampai pada kesimpulan bahwa motivasi dan integritas sangat penting. Seorang guru tidak dilahirkan dengan kualitas seperti ini, jadi apa yang bisa dilakukannya adalah untuk membangun karakter. Ketika seorang guru telah membuat dan menjaga komitmen, bahkan komitmen kecil, disitulah seorang guru mulai membangun integritas yang memberi kesadaran mengontrol diri dan keberanian serta kekuatan untuk menerima tanggung jawab.

Menurut Sarjana \& Khayati (2017) Pendidik yang berintegritas menjadi persyaratan bagi guru sebagai tenaga pendidik yang profesional. Guru yang berintegritas menjadi teladan dan contoh yang baik bagi siswa.

Sesuai dengan Peraturan Menteri Pendidikan Nasional RI No. 18 Tahun 2007 tentang sertifikasi bagi guru dalam jabatan, dijelaskan bahwa untuk uji kinerja guru, meliputi empat kopetensi yaitu: a) Kompetensi pedagogik, kemampuan yang berkaitan dengan kemampuan pemahaman terhadap siswa, merancang dan melaksanakan pembelajaran, melaksanakan evaluasi pembelajaran, mengembangkan potensi siswa untuk mengaktualisasi berbagai potensi yang dimilikinya. b) Kompetensi profesional, kemampuan yang berkenaan dengan penguasaan materi pembelajaran secara luas dan mendalam. Mencakup penguasaan substansi materi yang diajarkan di sekolah dan substansi keilmuan yang menaungi materinya, serta penguasaan terhadap struktur dan metodologi keilmuannya. c) Kompetensi kepribadian, kemampuan personal yang digambarkan sebagai guru yang memiliki kepribadian mantap dan stabil, dewasa, arif dan memiliki akhlak mulia yang dapat menjadi teladan bagi siswa. d) Kompetensi Sosial, berkomunikasi dan bergaul secara efektif baik dengan siswa maupun dengan sesama pendidik dan tenaga kependidikan, serta orang tua murid/wali siswa dan masyarakat sekitar (Departemen Pendidikan Nasional, 2007).

Secara sederhana kinerja OCB dapat dimaknai sebagai sikap atau perilaku organisasi yang berpihak dan mengabdi untuk kepentingan organisasi. Organ defines OCB as individual behavior that is discretionary, not directly or explicitly recognized by the formal reward system, and that in the aggregate promotes the effective functionaing of the organization. The personality foundation for these organization citizenship behaviors reflects the employee's predispositional traits to the cooperative, helpful, caring, and conscientious. The attitudinal foundation indicates that employee engage in OCBs in order to reciprocate the actions of their oragnizations (Luthans, 2008).

\section{METODOLOGI}

Metode penelitian yang dipergunakan adalah metode survey, yaitu metode penelitian yang digunakan untuk mengungkap hubungan antara variabel Educational leadership, integritas dengan kinerja OCB guru Pendidikan Anak Usia Dini di Kabupaten Bogor. Sesuai dengan judul dan masalah yang ada, pelaksanaan penelitian dilakukan melalui metode korelasional dengan konstelasi masalahnya sebagai berikut: 


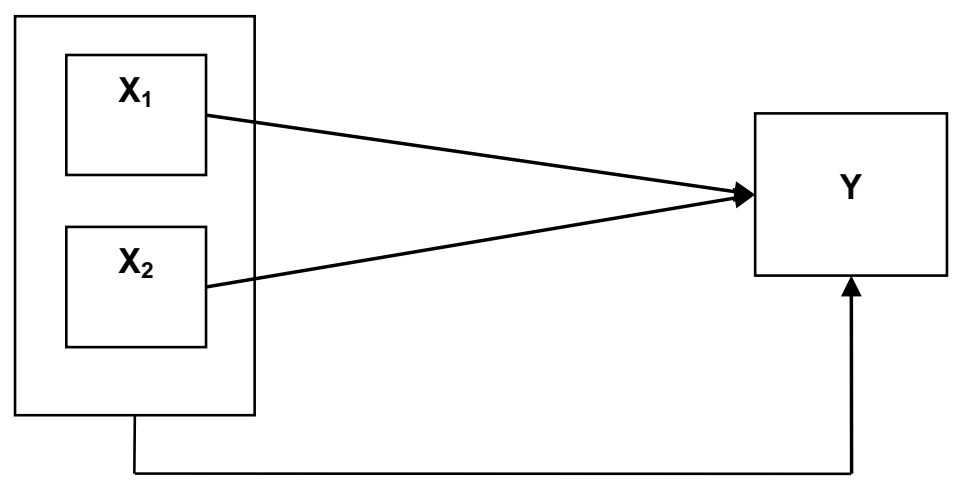

Keterangan :

\section{Gambar 1 Konstelasi Masalah}

$\mathrm{Y}=$ Variabel terikat: Kinerja OCB guru Pendidikan Anak Usia Dini Kabupaten Bogor

$\mathrm{X}_{1}=$ Variabel bebas $1:$ Educational leadership

$\mathrm{X}_{2}=$ Variabel bebas $2:$ Integritas

Konstelasi tersebut menginformasikan bahwa ada hubungan simultan antara variabel Educational leadership dengan kinerja (organizational citizenship behavior) guru swasta, terdapat hubungan secara simultan antara integritas dengan kinerja (organizational citizenship behavior) guru swasta dan ada hubungan simultan antara Educational leadership dan integritas secara bersama-sama dengan kinerja (organizational citizenship behavior) guru swasta.

Data analisis secara deskriptif dan infrensial. Analisis deskriptif terdiri atas penyajian data dengan histogram, perhitungan mean, median, modus, simpangan baku dan rentangan teoritik. Analisis infrensial (uji hipotesis) dengan analisis regresi dan korelasi, baik sederhana maupun ganda. Sebelumnya perlu diuji persyaratan analisis data, yaitu uji normalitas galat taksiran dan homogenitas varians $\mathrm{Y}$ atas $\mathrm{X}\left(\mathrm{X}_{1}\right.$ dan $\left.\mathrm{X}_{2}\right)$.

Menggunakan teknik analisa korelasional yang merupakan teknik analisa statistik mengenai hubungan antara dua variable. Adapun rumus yang digunakan untuk mengolah data tersebut adalah rumus. Product Moment.

$$
r x y=\frac{\sum X Y}{\sqrt{\left(\sum X^{2}\right)\left(\sum Y^{2}\right.}}
$$

Keterangan: rxy : Angka Indeks Korelasi “ $r$ ” product moment

$\mathrm{N}$ : Number of Cases

$\sum x y$ : Jumlah hasil perkalian antara skor $\mathrm{x}$ dan $\mathrm{y}$

$\sum x$ : Jumlah keseluruhan skor $\mathrm{x}$

$\sum \mathrm{y}$ : Jumlah keseluruhan skor y

\section{HASIL DAN PEMBAHASAN}

Hubungan antara Educational leadership $\left(\mathrm{X}_{1}\right)$ dengan Kinerja (Organizational Citizenship Behavior) (Y)

Hubungan antara variabel Educational leadership dengan kinerja (organizational citizenship behavior) dilakukan analisis regresi sederhana. Hasil analisis regresi sederhana tersebut mendapatkan persamaan $\hat{Y}=52,409+0,511 X_{1}$. Untuk pengujian keberartian dan linearitas regresi digunakan tabel ANAVA sebagai berikut : 
Tabel 1 Tabel ANAVA untuk Uji Signifikansi dan Linearitas Regresi $\hat{Y}=52,409+0,511 X_{1}$

\begin{tabular}{lcccccc}
\hline \multicolumn{1}{c}{ Variasi } & $\begin{array}{c}\text { Derajat } \\
\text { Kebebasan } \\
(\mathbf{d k})\end{array}$ & $\begin{array}{c}\text { Jumlah } \\
\text { Kuadrat } \\
(\mathbf{J K})\end{array}$ & $\begin{array}{c}\text { Kuadrat } \\
\text { Tengah } \\
(\mathbf{K T})\end{array}$ & $\mathbf{F}_{\text {hitung }}$ & $\mathbf{F}_{\text {tabel }}$ \\
\hline Total & 94 & & & & 0,05 & 0,01 \\
Koefisien (a) & 1 & & & & & \\
Regresi (b/a) & 1 & $5.916,754$ & $5.916,754$ & $77,04^{* *}$ & 3,10 & 6,92 \\
Sisa & 92 & $7.065,597$ & 76.800 & & & \\
Tuna Cocok Galat & 46 & $3.847,347$ & 83.638 & $1,195^{* *}$ & 1,60 & 1,75 \\
& 46 & $3.218,250$ & 69.962 & & & \\
\hline
\end{tabular}

Berdasarkan daftar ANAVA untuk uji keberartian dan linearitas regresi terlihat harga

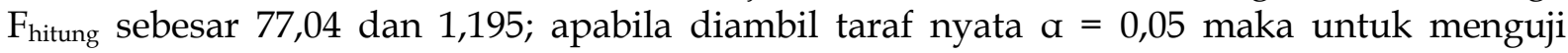
hipotesis nol (I) yaitu dari daftar distribusi $\mathrm{F}$ dengan $\mathrm{dk}$ pembilang $1 \mathrm{dan} d \mathrm{k}$ penyebut 92 diperoleh $\mathrm{F}_{\text {tabel }} \mathrm{a}=0,05$ sebesar 3,10; dan untuk menguji hipotesis nol (II) dengan $\mathrm{dk}$ pembilang 46 dan dk penyebut 46 diperoleh $F_{\text {tabel }} \alpha=0,05$ sebesar 1,60; dengan demikian hipotesis nol (I) ditolak karena $F_{\text {hitung }}>F_{\text {tabel, }}$, sehingga dari segi ini regresi diperoleh adalah signifikan. Hipotresis nol (II) diterima karena $\mathrm{F}_{\text {hitung }}<\mathrm{F}_{\text {tabel }}$ sehingga dapat dikatakan bahwa regresi linier.

Hubungan antara Educational leadership dengan kinerja (organizational citizenship behavior) dengan menggunakan persamaan regresi $\hat{Y}=52,409+0,511 X_{1}$. Pada persamaan regresi $\hat{Y}=52,409+0,511 X_{1}$ diinterpretasikan bahwa variabel Educational leadership $\left(X_{1}\right)$ dengan kinerja (organizational citizenship behavior) (Y) diukur dengan instrumen yang telah diuji validitas dan reliabilitasnya, maka setiap perubahan skor variabel pengetahuan tentang Educational leadership sebesar 1 point dapat diestimasikan skor kinerja (organizational citizenship behavior) akan berubah sebesar 0,511 pada arah yang sama dengan konstanta sebesar 52,409.

Pada uji hipotesis pertama ini diperoleh koefisien korelasi yang menunjukkan kekuatan hubungan antara variabel bebas $X_{1}$ dengan variabel terikat $Y\left(r_{\mathrm{y} 1}\right)$ sebesar 0,675. Dengan menggunakan kriteria uji tolak $\mathrm{H}_{0}$ jika harga $t_{\text {hitung }}>t_{\text {tabel }}$ pada $a=0,05 \mathrm{dan} d \mathrm{k}=94$, maka koefisien korelasi signifikan. Hasil pengujian memberikan hasil sebagai berikut :

Tabel 2 Uji Keberartian Koefisien Korelasi Nihil

$\left(\mathbf{r}_{\mathrm{y} 1}\right)$

\begin{tabular}{ccc}
\hline Koefisien Korelasi & $\boldsymbol{t}_{\text {hitung }}$ & $\boldsymbol{t}_{\text {tabel }}$ \\
\hline$r_{\mathrm{y} 1}=0,675$ & $8,78^{*}$ & 1,66 \\
\hline
\end{tabular}

\section{Keterangan :}

Harga $t_{\text {tabel }}$ adalah $t_{(0,05)(94)}=1,66$

* Koefisien korelasi signifikan

Uji $t$ diperoleh $t_{\text {hitung }}$ sebesar 8,78; harga $t_{\text {tabel }}$ pada distribusi " $t$ " dengan taraf nyata $a$ $=0,05$ untuk dk 94 diperoleh indeks $t_{\text {tabel }}$ sebesar 1,661 oleh karena $t_{\text {hitung }}>t_{\text {tabel }}$ yaitu 8,78 $>$ 1,66. Berarti koefisien korelasi antara Educational leadership $\left(\mathrm{X}_{1}\right)$ dengan kinerja (organizational citizenship behavior) $(\mathrm{Y})$ signifikan pada taraf nyata $a=0,05$ dengan demikian hipotesis nol $\left(\mathrm{H}_{0}\right)$ ditolak. Kesimpulan yang dapat diambil adalah terdapat hubungan positif yang signifikan antara Educational leadership $\left(\mathrm{X}_{1}\right)$ dengan kinerja (organizational citizenship behavior) (Y). Ini berarti, makin kuat Educational leadership, maka makin positif kinerja (organizational citizenship behavior). 
Hasil uji ini dilanjutkan dengan menghitung kekuatan Koefisien Korelasi Parsial yang mendeskripsikan hubungan antara Educational leadership $\left(X_{1}\right)$ dengan kinerja (organizational citizenship behavior) $(\mathrm{Y})$, jika variabel integritas guru $\left(\mathrm{X}_{2}\right)$ dikontrol menghasilkan koefisien $r_{y 1.2}=0,251$ dan $t_{\text {hitung }}=2,49$ sedangkan nilai $t_{\text {tabel }}$ pada taraf signifikansi 0,05 dan derajat kebebasan 94 adalah 1,66; sehingga $t_{\text {hitung }}>t_{\text {tabel }}$. Kondisi ini dapat diartikan walaupun variabel integritas guru dikontrol dari hubungan antara Educational leadership dengan kinerja (organizational citizenship behavior) tetap positif dan signifikan. (Perhitungan pada lampiran 6).

Jadi dapat disimpulkan bahwa Educational leadership berpengaruh atau berarti terhadap kinerja (organizational citizenship behavior). Kepemimpinan merupakan penggunaan pengaruh pemimpin dalam mengarahkan bawahannya guna mencapai tujuan tertentu. Pemimpin sangat penting dalam kegiatan manajemen, bahkan dikatakan bahwa pemimpin merupakan inti dari manajemen. Ini berarti bahwa manajemen akan tercapai tujuannya jika ada pemimpin.

Kepemimpinan hanya dapat dilaksanakan oleh seorang pemimpin. Seorang pemimpin adalah seseorang yang mempunyai keahlian memimpin, mempunyai kemampuan mempengaruhi pendirian atau pendapat orang atau sekelompok orang. Seorang pemimpin adalah seseorang yang aktif membuat rencana-rencana, mengkoordinasi, melakukan percobaan dan memimpin pekerjaan untuk mencapai tujuan bersama-sama. Pada awalnya teori kepemimpinan terfokus pada kualitas yang berbeda antara pemimpin dan bawahan. Saat ini, menurut Wagner, banyak teori kepemimpinan yang muncul dan dapat dikelompokkan menjadi delapan tipe utama sebagai berikut:

"Great Man" Theories: Great Man theories assume that the capacity for leadership is inherent - that great leaders are born, not made. Trait Theories: Trait theories often identify particular personality or behavioural characteristics shared by leaders. Contingency Theories: Contingency theories of leadership focus on particular variables related to the environment that might determine which particular style of leadership is best suited for the situation. Situational Theories: Situational theories propose that leaders choose the best course of action based upon situational variable. Behavioural Theories: Behavioural theories of leadership are based upon the belief that great leaders are made, not born. Participative Theories: Participative leadership theories suggest that the ideal leadership style is one that takes the input of others into account. Management Theories: Management theories (also known as "Transactional theories") focus on the role of supervision, organization, and group performance. Relationship Theories: Relationship theories (also known as "Transformational theories") focus upon the connections formed between leaders and followers (Wagner, 2008).

Pertama, Teori "Great Man" yang berasumsi bahwa kapasitas pemimpin adalah "inheren" - pemimpin besar dilahirkan, bukan dibuat. Kedua, Teori Sifat, sering menunjukkan kepribadian atau karakteristik tertentu. Ketiga, Teori Kontingensi, teori yang fokus pada variabel tertentu berhubungan dengan lingkungan yang menunjukkan gaya kepemimpinan tertentu yang sesuai dengan situasi. Keempat, Teori Situasional, pemimpin memilih tindakan yang tepat sesuai dengan variabel situasi. Kelima, Teori Perilaku, teori kepemimpinan yang didasarkan pada kepercayaan bahwa pemimpin yang besar dibuat, bukan dilahirkan. Keenam, Teori Partisipatif, teori yang menyarankan bahwa gaya kepemimpinan yang ideal adalah yang sesuai untuk orang lain. Ketujuh, Teori Manajemen, kepemimpinan yang fokus pada supervisi, organisasi, dan kinerja kelompok. Kedelapan, Teori Hubungan, kepemimpinan yang fokus pada hubungan yang dibentuk antara pemimpin dengan bawahan (Wagner, 2008).

Kepemimpinan secara harfiah berasal dari kata pimpin. Kata pimpin mengandung pengertian mengarahkan, membina atau mengatur, menuntun dan juga menunjukkan atau mempengaruhi. Aktivitas mempengaruhi merupakan inti dari kepemimpinan, agar 
seseorang dapat menjadi pemimpin yang efektif, dia harus mampu mempengaruhi orang lain agar mau menjalankan permintaan, mendukung, dan mengimplementasikan kebijakan. Steven L. McShane, Marry Ann Von Ginow mendefinisikian kepemimpinan sebagai berikut, "leadership is about influencing, motivating, and enabling others to contribute toward the effectiveness and success of the organizations of wich they are members" (McShane \& Glinow, 2013). Kepemimpinan merupakan aktivitas mempengaruhi, memotivasi, dan memungkinkan orang lain untuk berkontribusi ke arah organisasi yang sukses dan efektif pada anggota-anggotanya.Berikut adalah teori path-goal yang menjelaskan dampak perilaku pemimpin pada motivasi bpengikutnya, kepuasan, dan kinerjanya, sehingga dari penjelasan tersebut diduga terdapat hubungan antara educational leadreship dengan kinerja (organizational citizenship behavior).

\section{Hubungan antara Integritas Guru $\left(\mathrm{X}_{2}\right)$ dengan Kinerja (Organizational Citizenship Behavior) $(\mathrm{Y})$}

Hubungan antara variabel integritas guru dengan kinerja (organizational citizenship behavior) dilakukan analisis regresi sederhana. Hasil analisis regresi sederhana tersebut mendapatkan persamaan $\hat{Y}=52,079+0,532 X_{2}$. Untuk pengujian keberartian dan linearitas regresi digunakan tabel ANAVA sebagai berikut :

Tabel 3 Tabel ANAVA untuk Uji Signifikasi dan Linearitas Regresi $\hat{Y}=52,079+0,532 X_{2}$

\begin{tabular}{lcccccc}
\hline \multicolumn{1}{c}{ Variasi } & $\begin{array}{c}\text { Derajat } \\
\text { Kebebasan } \\
\text { (dk) }\end{array}$ & $\begin{array}{c}\text { Jumlah } \\
\text { Kuadrat } \\
\text { (JK) }\end{array}$ & $\begin{array}{c}\text { Kuadrat } \\
\text { Tengah } \\
(\text { KT) }\end{array}$ & F Fitung & $\mathbf{F}_{\text {tabel }}$ \\
\hline Total & 94 & & & & 0,05 & 0,01 \\
Koefisien (a) & 1 & & & & & \\
Regresi (b/a) & 1 & $5.868,568$ & $5.868,568$ & $75,89^{* *}$ & 3,10 & 6,92 \\
Sisa & 92 & $7.113,783$ & 77.324 & & & \\
Tuna Cocok & 42 & $4.049,649$ & 96.420 & $1,573^{* *}$ & 1,60 & 1,75 \\
Galat & 50 & $3.064,133$ & 61.283 & & & \\
\hline
\end{tabular}

Berdasarkan daftar ANAVA untuk uji keberartian dan linearitas regresi terlihat harga

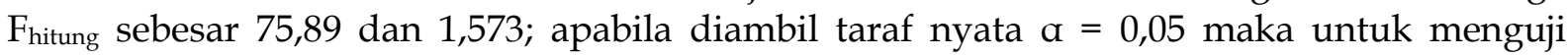
hipotesis nol (I) yaitu dari daftar distribusi $\mathrm{F}$ dengan dk pembilang $1 \mathrm{dan}$ dk penyebut 92 diperoleh $\mathrm{F}_{\text {tabel }}$ pada $\alpha=0,05$ sebesar 3,10; dan untuk menguji hipotesis nol (II) dengan $\mathrm{dk}$ pembilang 42 dan $\mathrm{dk}$ penyebut 50 diperoleh $\mathrm{F}_{\text {tabel }}$ pada $\alpha=0,05$ sebesar 1,60; dengan demikian hipotesis nol (I) ditolak karena $F_{\text {hitung }}>F_{\text {tabel }}$ maka koefisien arah regresi nyata sifatnya, sehingga dari segi ini regresi diperoleh adalah signifikan. Hipotesis nol (II) diterima karena $\mathrm{F}_{\text {hitung }}<\mathrm{F}_{\text {tabel }}$ sehingga dapat dikatakan bahwa regresi linier.

Hubungan antara integritas guru dengan kinerja (organizational citizenship behavior) dengan menggunakan persamaan regresi $\hat{Y}=52,079+0,532 X_{2}$. Pada persamaan regresi $\hat{Y}=$ $52,079+0,532 \mathrm{X}_{2}$ diinterpretasikan bahwa variabel integritas guru $\left(\mathrm{X}_{2}\right)$ dengan kinerja (organizational citizenship behavior) $(\mathrm{Y})$ diukur dengan instrumen yang telah diuji validitas dan reliabilitasnya, maka setiap perubahan skor variabel integritas guru $\left(X_{2}\right)$ sebesar 1 point dapat diestimasikan skor kinerja (organizational citizenship behavior) (Y) akan berubah sebesar 0,532 pada arah yang sama dengan konstanta sebesar 52,079.

Pada uji hipotesis kedua ini diperoleh koefisien korelasi yang menunjukkan kekuatan hubungan nihil antara variabel bebas $X_{2}$, dengan variabel terikat $Y\left(r_{\mathrm{y} 2}\right)$ sebesar 0,672 . Dengan menggunakan kriteria uji tolak $\mathrm{H}_{0}$ jika harga $t_{\text {hitung }}>t_{\text {tabel }}$ pada $\alpha=0,05 \mathrm{dan} \mathrm{dk}=94$, maka koefisien korelasi signifikan. Hasil pengujian memberikan hasil pada tabel di bawah ini : 
Tabel 4 Uji Keberartian Koefisien Korelasi Nihil $\left(\mathbf{r}_{\mathrm{y} 2}\right)$

\begin{tabular}{cll}
\hline Koefisien Korelasi & $\mathbf{t}_{\text {hitung }}$ & $\mathbf{t}_{\text {tabel }}$ \\
\hline $\mathrm{r}_{\mathrm{y} 2}=0,672$ & $8,71^{*}$ & 1,66 \\
\hline
\end{tabular}

\section{Keterangan :}

Harga $\mathrm{t}_{\text {tabel }}$ adalah $\mathrm{t}_{(0,05)(94)}=1,66$

* Koefisien korelasi signifikan

Uji $t$ diperoleh $t_{\text {hitung }}$ sebesar 8,71 ; harga $t_{\text {tabel }}$ pada distribusi " $\mathrm{t}$ " dengan taraf nyata a $=0,05$ untuk dk 94 diperoleh indeks $t_{\text {tabel }}$ sebesar 1,66; oleh karena $t_{\text {hitung }}>t_{\text {tabel }}$ yaitu 8,71 > 1,66. (Perhitungan pada lampiran 6) Berarti koefisien korelasi antara integritas guru $\left(X_{2}\right)$ dengan kinerja (organizational citizenship behavior) $(\mathrm{Y})$ signifikan pada taraf nyata a $=0,05$ dengan demikian hipotesis nol $\left(\mathrm{H}_{0}\right)$ ditolak. Kesimpulan yang dapat diambil adalah terdapat hubungan positif yang signifikan antara integritas guru $\left(\mathrm{X}_{2}\right)$ dengan kinerja (organizational citizenship behavior) (Y). Ini berarti, makin kuat integritas guru, maka makin positif kinerja (organizational citizenship behavior).

Hasil uji ini dilanjutkan dengan menghitung kekuatan Koefisien Korelasi Parsial yang mendeskripsikan hubungan antara integritas guru $\left(\mathrm{X}_{2}\right)$ dengan kinerja (organizational citizenship behavior) $(\mathrm{Y})$, jika variabel Educational leadership $\left(\mathrm{X}_{1}\right)$ dikontrol menghasilkan koefisien $r_{y 2.1}=0,238$ dan $t_{\text {hitung }}=2,35$ sedangkan nilai $t_{\text {tabel }}$ pada taraf signifikansi 0,05 dan derajat kebebasan 94 adalah 1,66; sehingga $t_{\text {hitung }}>t_{\text {tabel }}$. Kondisi ini dapat diartikan walaupun variabel Educational leadership dikontrol dari hubungan antara integritas guru dengan kinerja (organizational citizenship behavior) tetap positif dan signifikan.

Jadi dapat disimpulkan bahwa integritas guru berpengaruh atau berarti terhadap kinerja (organizational citizenship behavior). Binney dan Smith mengatakan bahwa orang yang memiliki integritas memiliki ciri perilaku; membawakan diri dengan standar etika tertinggi, bertindak tunduk dengan jujur, terbuka dan lugas, memperlakukan orang lain tanpa melihat derajatnya serta berpembawaan sederhana. Integritas merupakan unsur dari karakter yang ditampilkan ketika seseorang mencapai kesesuaian antara apa yang diketahui, apa yang dikatakan dan apa yang dilakukannya. penelitian Permatasari (2012) menyatakan gaya berpikir, integritas dan usia tidak berinteraksi dalam memengaruhi perilaku kontraproduktif.

Barry L. Reece mengatakan, bahwa ketika perilaku Anda adalah selaras dengan nilainilai yang ada, mempraktekkan apa yang Anda percaya, maka Anda memiliki integritas. Ketika Anda mengatakan satu hal tetapi melakukan sesuatu yang lain , Anda tidak memiliki integritas (Reece, 2011). Untuk membangun integritas guru yang baik perlu adanya kinerja (organizational citizenship behavior) dari semua warga sekolah dan tentunya kinerja (organizational citizenship behavior) dapat timbul jika seseorang memiliki integritas yang baik. Dari penjelasan tersebut diduga terdapat hubungan antara integritas dengan kinerja (organizational citizenship behavior).

Hubungan antara Educational leadership $\left(\mathrm{X}_{1}\right)$, Integritas Guru $\left(\mathrm{X}_{2}\right)$ secara bersama-sama dengan Kinerja (Organizational Citizenship Behavior) (Y)

Bentuk hubungan antara variabel Educational leadership $\left(\mathrm{X}_{1}\right)$, integritas guru $\left(\mathrm{X}_{2}\right)$ secara bersama-sama dengan kinerja (organizational citizenship behavior) (Y) dilakukan analisis regresi berganda. Hasil analisis regresi berganda yang menghasilkan persamaan regresi $\hat{Y}=$ $47,806+0,281 X_{1}+0,277 X_{2}$. adapun pengujian keberartian regresi berganda diperlukan Daftar ANAVA sebagai berikut : 
Tabel 5 Tabel ANAVA untuk Regresi Berganda

$\hat{Y}=47,806+0,281 X_{1}+0,277 X_{2}$

\begin{tabular}{lcccccc}
\hline Variasi & $\begin{array}{c}\text { Derajat } \\
\text { Kebebasan } \\
(\mathbf{d k})\end{array}$ & $\begin{array}{c}\text { Jumlah } \\
\text { Kuadrat (JK) }\end{array}$ & $\begin{array}{c}\text { Kuadrat } \\
\text { Tengah } \\
(\mathbf{K T})\end{array}$ & $\mathbf{F}_{\text {hitung }}$ & $\mathbf{F}_{\text {tabel }}$ \\
\hline Total & 94 & & & & 0,05 & 0,01 \\
Direduksi & 2 & $6.315,493$ & $3.157,747$ & $43,102^{* *}$ & 3,10 & 4,85 \\
Regresi & 91 & $6.666,858$ & 73.262 & & & \\
Sisa & &
\end{tabular}

\section{Keterangan :}

Harga $\mathrm{F}_{\text {tabel }}$ adalah $\mathrm{F}_{(0,05)(2: 91)}=3,10$ dan $\mathrm{F}_{(0,01)(2: 91)}=4,85$

** : Regresi sangat signifikan, $\mathrm{F}_{\text {hitung }}>\mathrm{F}_{\text {tabel }}=0,01$

Pada uji keberartian koefisien regresi secara keseluruhan menghasilkan $\mathrm{F}_{\text {hitung }}$ sebesar 43,102; sedangkan berdasarkan daftar distribusi $\mathrm{F}$ dengan $\mathrm{dk}$ pembilang $2 \mathrm{dan}$ dk penyebut 91 pada taraf nyata $a=0,05$ diperoleh $F_{\text {tabel }}$ sebesar 3,10; dengan demikian nilai $F_{\text {hitung }}>F_{\text {tabel }}$ sehingga dapat dikatakan bahwa persamaan regresi yang diperoleh sangat signifikan.

Analisis korelasi berganda antara $X_{1}$ dan $X_{2}$ dengan $Y$ menghasilkan koefisien korelasi berganda $\left(\mathrm{R}_{\mathrm{y} 1.2}\right)$ sebesar $0,697 . \mathrm{R}_{\mathrm{y}}$ adalah koefisien korelasi jamak untuk parameter populasi. Rumus yang digunakan untuk menguji keberartian koefisien korelasi ganda adalah dengan uji $\mathrm{F}$, yaitu :

$$
\mathrm{F}=\frac{R^{2} / k}{\left(1-R^{2}\right) /(n-k-1)}
$$

Dimana $\mathrm{n}$ adalah banyaknya pasangan data, dan $\mathrm{k}$ adalah banyaknya variabel bebas. Kriteria uji tolak $\mathrm{H}_{0}$ jika harga $\mathrm{F}_{\text {hitung }}>\mathrm{F}_{\text {tabel }}$ pada $\alpha=0,05$, maka koefisien hasil pengujian sebagai berikut :

Tabel 6 Uji Keberartian Korelasi Ganda $\left(\mathbf{R}_{\mathrm{y} 1.2}\right)$

\begin{tabular}{crrr}
\hline Koefisien Korelasi $\left(\mathbf{R}_{\mathbf{y 1 . 2}}\right)$ & $\mathbf{F}_{\text {hitung }}$ & \multicolumn{2}{c}{$\mathbf{F}_{\text {tabel }}$} \\
& $42,92^{* *}$ & 3,10 & 0,01 \\
\hline 0,697 & 42,85 \\
\hline
\end{tabular}

\section{Keterangan :}

Harga $\mathrm{F}_{\text {tabel }}$ adalah $\mathrm{F}_{(0,05)(2: 91)}=3,10$ dan $\mathrm{F}_{(0,01)(2: 91)}=4,85$

** $\quad$ Regresi sangat signifikan $\mathrm{F}_{\text {hitung }}>\mathrm{F}_{\text {tabel }}=0,01$

Berdasarkan kesimpulan tersebut hipotesis nol ditolak. Kesimpulannya ialah terdapat hubungan positif yang signifikan antara Educational leadership dan integritas guru secara bersama-sama dengan kinerja (organizational citizenship behavior). Artinya, makin kuat Educational leadership dan integritas guru, maka makin positif kinerja (organizational citizenship behavior).

Berdasarkan tabel koefisien korelasi berganda diatas, diperoleh koefisien determinasi hubungan antara Educational leadership $\left(\mathrm{X}_{1}\right)$, integritas guru $\left(\mathrm{X}_{2}\right)$ secara bersama-sama dengan kinerja (organizational citizenship behavior) $(Y)$ sebesar $(0,697)^{2}=0,486$. Hal ini menunjukkan $48,6 \%$ variasi kinerja (organizational citizenship behavior) dapat dijelaskan oleh variabel Educational leadership dan integritas guru secara bersama-sama.

Hasil pengujian terhadap semua hipotesis yang diajukan dapat disimpulkan bahwa keseluruhan hipotesis penelitian yang dirumuskan pada Bab II dapat diterima. Dengan demikian berarti kineja OCB sebesar $48,6 \%$ dapat diperjelas oleh variabel Educational leadership dan integritas guru. 
Kinerja OCB sebagai perilaku individu yang memilih, tidak secara langsung atau secara eksplisit diakui oleh sistem perhargaan formal, dan secara agregat mempromosikan fungsi efektif organisasi. Kepribadian dasar untuk perilaku ini mencerminkan sifat-sifat personil organisasi, kecenderungan karyawan untuk bekerjasama, membantu, peduli, dan bersungguh-sungguh. Landasan sikap menunjukkan bahwa karyawan terlibat perilaku personil organisasi untuk mengabdi pada organisasi mereka (Luthans, 2008)

Kinerja menurut Colquitt, "job performance is formally defined as the value of the set of employee behaviors that contribute, either positively or negatively, to organizational goal accomplishment" (Colquitt, Lepine, \& Wesson, 2009). Kinerja itu adalah perilaku dari kontribusi karyawan baik secara positif ataupun negatif untuk tujuan organisasi. Kinerja menurut pendapat Thomas S. Bateman adalah "performance measures fall into one of three basic categories: traits, behaviors, and result" (Bateman \& Snell, 1999). Kinerja itu dapat diukur dengan tiga kategori dasar yakni sifat, perilaku dan hasil. Hasil penelitian Auliya, Thomas, \& Latifah (2013) didapatkan bahwa dengan mengadakan rapat-rapat pembinaan, kinerja guru dapat selalu terkontrol sehingga dapat menumbuhkan kinerja yang lebih baik lagi.

Sedangkan penelitian Jamma (2016) menemukan bahwa untuk meningkatkan etos kerja guru dapat dilakukan melalui peningkatan kepuasan kerja guru bersamaan dengan perbaikan gaya kepemimpinan kepala sekolah guru. Dapat dikatakan bahwa gaya kepemimpinan menentukan kinerja guru. Senada dengan temuan tersebut, Ramadoni \& Arifin (2016) mendapatkan bahwa dalam meningkatkan kinerja guru, antara lain dengan memberikan reward pada guru yang berprestasi melalui penilaian rapot guru yang diberikan setiap awal semester untuk diisi sendiri dan di akhir semester akan di setorkan ke kepala sekolah melalui koordinator jenjang.

Colquitt et al., (2009) secara umum kinerja dipengaruhi oleh komponen: mekanisme individual, karakteristik individu, mekanisme kelompok, dan mekanisme organisasi. Lebih lanjut Colquitt menggambarkan keterkaitan keempat komponen tersebut sebagaimana terlihat pada gambar 1 .

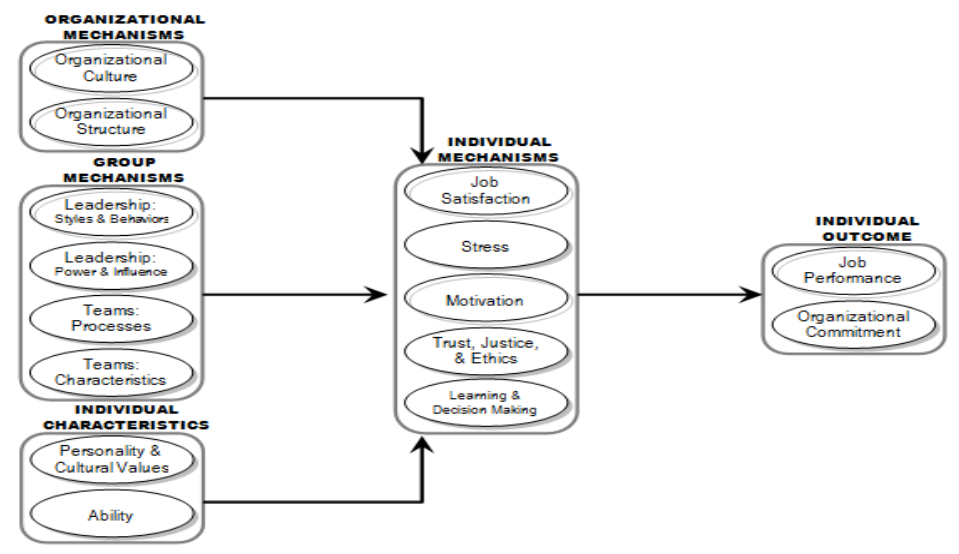

Gambar 1 Diagram Kinerja Menurut Teori Colquitt

Menurut Fauyan (2019) integritas guru diwujudkan dengan kemampuannya dalam nenyiapkan perangkat pembelajaran berupa media pembelajaran dan penguasaan materi serta pemahaman terhadap karakter peserta didiknya.

\section{SIMPULAN}

Educational leadership tidak sendirian mempengaruhi kinerja organizational citizenship behavior $(O C B)$, tetapi juga tergantung pada integritas guru PAUD. Terdapat hubungan signifikan antara Educational leadership dan integritas guru PAUD dengan kinerja organizational citizenship behavior (OCB). 


\section{UCAPAN TERIMA KASIH}

Peneliti mengucapkan terima kasih kepada kepala sekolah Pendidikan Anak Usia Dini se Kabupaten Bogor yang telah membantu dalam penelitian kami dan ketua yayasan STIA Menara Siswa yang telah memfasilitasi penelitian kami serta rekan-rekan dosen yang telah memberikan suport kepada kami.

\section{DAFTAR PUSTAKA}

Aqib, Z. (2002). Profesionalisme Guru dalam Pembelajaran. Surabaya: Insan Cendekia.

Auliya, U. U., Thomas, P., \& Latifah, L. (2013). Economic Education Analysis Journal. Economic Education Analysis Journal, 2(1), 18-23.

Bateman, T. S., \& Snell, S. A. (1999). Management Building Competitive Advantage. New York: McGraw-Hill.

Colquitt, J. A., Lepine, J. A., \& Wesson, M. J. (2009). Organizational Behavior. New York: McGraw-Hill, Inc.

Departemen Pendidikan Nasional. (2007). Kebijakan Pendidikan di Indonesia, Jakarta: Depdiknas. Jakarta: Departemen Pendidikan Nasional.

Fauyan, M. (2019). Developing Interactive Multimedia Through Ispring on Indonesian Language Learning with The Insights of Islamic Values in Madrasah Ibtidaiyah. Al Ibtida: Jurnal Pendidikan Guru 177. https:// doi.org/10.24235/al.ibtida.snj.v6i2.4173

George, J., \& Jones, G. (2002). Uderstanding and Managing Organizational Behavior. New Jersey: Prentice Hall.

Jamma, H. (2016). Hubungan Gaya Kepemimpinan dan Kinerja dengan Etos Kerja Guru Sekolah Dasar di Kota Padang Panjang. Al-Fikrah: Jurnal Manajemen Pendidikan, 1(2), 149. https:/ / doi.org/10.31958/jaf.v1i2.360

Luthans, F. (2008). Organizational Behavior Eleventh Edition. Singapore: McGraw-Hill International Edition.

McShane, S., \& Glinow, M. Von. (2013). Organizational Behavior, International Edition (New York: McGraw-Hill Education, Inc, 2013), h.367.h.361. New York: McGraw Hill.

Moideenkutty, U. (2005). Organizational citizenship behavior development experiences: Do role definitions moderate relationship? The Journal of Behavior and Applied Management, 6(2), 91-108.

Mundia Sari, K., \& Setiawan, H. (2020). Kompetensi Pedagogik Guru dalam Melaksanakan Penilaian Pembelajaran Anak Usia Dini. Jurnal Obsesi: Jurnal Pendidikan Anak Usia Dini, 4(2), 900. https:/ / doi.org/10.31004/obsesi.v4i2.478

Permatasari, M. (2012). Pengaruh Gaya Berpikir, Integritas Dan Usia Pada Perilaku Kerja Yang Kontraproduktif. Jurnal Psikologi Ulayat, 1(1), 75-88. https://doi.org/10.24854/jpu12012-11

Ramadoni, W., \& Arifin, I. (2016). Kepemimpinan Kepala Sekolah Dalam Upaya Peningkatan Kinerja Guru (Studi Multi Kasus Di Paud Islam Sabilillah Dan Sdn Tanjungsari 1 Kabupaten Sidoarjo). 1500-1504.

Reece, B. L. (2011). Effective Human Realtions, Interpersonal and Organizational Applications. Ohio: Cengage Learning.

Sarjana, S., \& Khayati, N. (2017). Pengaruh Etika, Perilaku, Dan Kepribadian Terhadap Integritas Guru. Jurnal Pendidikan Dan Kebudayaan, 1(3), 379. https:// doi.org/10.24832/jpnk.v1i3.450

Wagner, K. Van. (2008). Leadership Theories. 